\section{Bushuyev 5., Kozyr B., Zaprivoda A.}

\title{
STRATEGIC AUDIT OF INFRASTRUCTURE PROJECTS AND PROGRAMS
}

В якості об’єкта дослідження розглядаються моделі, методи та процеси проведення стратегічного аудиту інфраструктурних проектів та програм. Проблеми складних інфраструктурних проектів та програм, які виконуються в умовах невизначеності, пов'язані з уточненням та змінами стратегї під впливом критичних зовнішніх та внутрішніх впливів. Аналіз факторів, що формують стратегію реалізацї інфраструктурних проектів та програм з урахуванням невизначеності, відбувається в рамках РEST-аналізу, який є невід'ємною частиною методики стратегічного аудиту. Визначено взаємозв'язок понять «стратегія розвитку організацї» $i$ «стратегічний аудит інфраструктурних проектів та програм». Обгрунтовані підходи до аудиторської оцінки здатності реагування системи управління інфраструктурними проектами на фактори невизначеності, зміни зовнішнього середовища і ступеня адекватності організаційно-економічних елементів системи управління, що забезпечують досягнення стратегічних цілей. Представлено алгоритм проведення стратегічного аудиту на моделі технологічної зрілості організації (IPMA ОСВ). У моделі, яка застосовується, оцінюється п’ять груп елементів компетентності організації в галузі управління проектами:

1) керівництво проектами, програмами $і$ портфелями як складова корпоративного управління, що пов'язана з проектами, програмами та портфелями;

2) управління проектами, програмами та портфелями як складова системи управління організацією та реалізується керівниками різних рівнів постійних і тимчасових підрозділів організачї;

3) узгодження проектів, програм і портфелів, що забезпечує досягнення цілей і очікувань, встановлених вищим керівництвом;

4) ресурсне забезпечення проектів, програм та портфелів, яке направлено на досягнення цілей $і$ очікувань, встановлених вищим керівництвом;

5) компетентність співробітників проектів, програм та портфелів, яка пов'язана з розвитком компетентності, збільшенням продуктивності роботи і стимулюванням співробітників, працюючих в проектах, програмах, портфелях.

Наведені приклади форм самооцінки по стратегічним аспектам впровадження інфраструктурних проектів та програм. Показано приклад форми самооцінки менеджера проекту та його команди по поведінковим компетенціям у ході досягнення стратегічних иілей. Наведено приклад аудиторсъкої оцінки щодо стратегї впровадження проекту Конфаймент Чорнобильської АЕС (Україна). У висновках підкреслено важливість застосування інструментів стратегічного аудиту в процесі впровадження інфраструктурних проектів та програм.

Ключові слова: стратегічний аудит, модель технологічної зрілості організації, стратегія інфраструктурного проекту, самооцінка рівня компетентності організації.

\section{Introduction}

The world is rapidly transforming. The life cycle of knowledge and technology management of complex projects and programs is significantly reduced. The technical and technological complexity of infrastructure projects and programs is increased by innovation. These key trends form significant challenges in the development of project and program management systems.

Thus, applying proven best practice (benchmarking) is no longer a way forward. Forming a vision, goals and strategies for the implementation of infrastructure projects in advance makes us tough, not flexible. When the creation of a project or program begins with a focus on what is valuable for our clients, it is enough for us to use the best practice. But the complexity and innovation of infrastructure projects and programs creates a number of challenges. One of the answers to these challenges is carefully flexible work on the management of infrastructure projects and programs. Infrastructure project management teams learn to distinguish between what is valuable and irrelevant, a path that has been followed for decades in a row of management methodologies. In a number of infrastructure projects, the first steps have been taken to introduce the necessary economical/flexible transition, which supports sustainability of development and adaptability to turbulent environmental changes. In the conditions of modern destructive economic relations in the world community, the problem of choosing the strategy of infrastructure projects as a driver for the development of countries is vital and relevant. The difficulties of developing an adequate strategy for infrastructure projects and programs open up new ways for qualitative changes to audit activities [1,2]. 


\section{The object of research and its technological audit}

The object of research is the models, methods and processes for conducting a strategic audit of infrastructure projects and programs. Today, a well-built strategy for the implementation of infrastructure projects and programs is the determining factor for success. This strategy:

- integrates infrastructure program management teams with an organizational mission and vision of the customer and other key stakeholders;

- ensures the ongoing activities of the infrastructure project or program to form an approach to management; - identifies, evaluates and analyzes critical success factors for infrastructure projects and programs;

- identifies, evaluates and analyzes key performance indicators for the implementation of infrastructure programs. Building a strategy for infrastructure projects and programs that meets these requirements in the face of uncertainty and critical environmental impacts is a complex scientific problem of great practical importance.

Thus, the uncertainty of conditions and the critical effects of the environment of infrastructure projects and programs are characterized by shortcomings that are inherent in this object of research in the existing conditions of operation.

One of the most problematic places is the construction of models and methods for conducting a strategic audit of infrastructure projects and programs that are implemented under conditions of uncertainty of success criteria, a system of created values, technical and technological solutions, goals and management processes.

Strategic audit is the verification and assessment of the quality of the work of departments of an organization, project, or program in which strategic management is conducted. Such an audit can be comprehensive, that is, affect the stages of the strategic management process, or directional - affect only part of the process.

Strategic audit is an examination of the achievement of the objectives of infrastructure projects and programs. When conducting a strategic audit, the auditor assesses the results of the strategic analysis conducted by the organization, made a strategic choice and implementation of the strategy, as well as monitoring its implementation. At the same time, the qualitative indicators of goal setting and goal achievement become dominant, especially at the levels of performance audit and strategic audit. This requires the development of appropriate methods and approaches during the audit $[1,3]$.

A strategic audit of infrastructure projects and programs reveals the degree to which the policy is related to the specifics of the project and the external conditions for its implementation. Each part of a strategic audit is based on a respective area of strategic accounting and strategic analysis. All of this merges together in the accounting and analytical support for making strategic decisions, in conjunction with the strategy for the development of the infrastructure project is subject to a strategic audit.

In the conditions of economic crisis, the problem of successful implementation of infrastructure projects can be solved by forming a sound strategy for the development of an organization that implements a project, and carrying out activities aimed at achieving the objectives of the project. In this regard, in order to increase the degree of substantiation of strategic management, strategic audit is important, which provides for the formation of complete information about the future development of an organization under the influence of internal and external factors.

The general vector of development of a strategic audit from the moment of its occurrence up to the present time assumed that auditors should only perform certain technical and tactical procedures aimed at confirming the reliability of the reporting data used for short-term management decisions by various groups of stakeholders. In the audit reports there was no information necessary to achieve the long-term goals of the economic entity and stimulating the dialectics of the qualitative development of the financial and economic state of the infrastructure project or program.

The help of the infrastructure project or program in the formation of a strategy with the subsequent audit control over the implementation will allow promptly reacting to the constantly changing influence of external and internal factors. And thereby achieve a stable development of organizations working in turbulent conditions.

Thus, the audit of the development strategy of the organization in modern conditions becomes important, and the problems of determining its goals, structure and models and methods are promising.

\section{The aim and objectives of research}

The aim of research is examination of the content and processes of the strategic audit as a direction of the audit activities of infrastructure projects and programs.

To achieve this aim it is necessary to perform the following objectives:

1. To determine the interrelation of «organization development strategy» and «strategic audit of infrastructure projects and programs» concepts.

2. To substantiate the approaches to the audit assessment of the ability of the infrastructure project management system to respond to factors of uncertainty, changes in the external environment and the degree of adequacy of the organizational and economic elements of the management system ensuring the achievement of strategic goals.

\section{Research of existing solutions of the problem}

The main directions of solving the problems of building and implementing an effective strategy for the implementation of infrastructure projects and programs under conditions of uncertainty and turbulent environmental influences identified in the world resources can be distinguished [1,2]. But these studies did not consider the models and methods of strategic audit of infrastructure projects and programs that are temporary organizations with the formation of culture during the implementation of a project or program. The question of creating an effective strategy in the face of uncertainty under the influence of a turbulent environment was also considered.

The works [3, 4] are devoted to the formation of a strategy for projects and programs, but the issues associated with complex infrastructure projects that are being implemented under conditions of uncertainty and critical environmental influences have not been resolved.

In [5], a look at the application of knowledge ontologies for evaluating strategies is provided. However, this 
work does not disclose the use of knowledge systems for auditing strategies of infrastructure projects and programs.

The authors of [6] defined a model of organizational competence. This model is partially applied as a base for conducting a strategic audit in this study. At the same time, there are still questions related to modeling uncertainty in the strategy of infrastructure projects and programs.

Tools for analyzing strengths and weaknesses are described in [7]. These tools are used in this study to analyze proposals for the application of the proposed models and methods for conducting a strategic audit of infrastructure projects.

The work [8] is devoted to the visualization of strategic decisions of project management, while it covers only part of the strategic audit process.

An alternative solution to the problem described in [9]. This option does not provide for a strategic audit in a commercial company. At the same time, the issues of application in temporary organizations, which are infrastructure projects, remained outside of the research.

The paper [10] explores issues of strategic gaps in the development of organizations. According to the authors of this work, the key problem of strategic management is the imperfection of the implementation of audit tools in the practice of corporate management.

In papers $[11,12]$, the application of the competencebased model of project management in the development of organizations and the tools for determining organizational pathologies are shown. However, outside of these studies are issues of audit strategies for infrastructure projects and programs.

Thus, the results of the analysis allow to conclude that the problems associated with the development and application of models and methods for strategic audit of infrastructure projects and programs under conditions of uncertainty and turbulent environmental influences have not been resolved.

\section{Methods of research}

Based on the methods of analysis and synthesis, various approaches to the definition of a strategic audit are presented, and its content is disclosed by summarizing. Fundamental principles and concepts of management and strategic audit, works of domestic and foreign authors were used as source materials. As a result, the place of strategic audit in the theory and practice of auditing is clarified. The most important aspects in the assessment by the auditor of external and internal factors that have a significant impact on the implementation of the development strategy of the organization are highlighted. The structure of strategic audit is defined in the form of various strategies. As a tool for its implementation, it is proposed to use of elements of the PEST analysis method.

In the conditions of the economic crisis, a strategic audit of infrastructure projects and programs contributes to the rapid response of customers to the constantly changing influence of external and internal factors.

A strategic audit is conducted when the strategy has already been developed, adopted, and its implementation has begun. During its conduct, it is important for the auditor to understand how the organization's activities comply with the requirements, environmental changes, and perceptions about possible actions of competitors and regulators in the current and future conditions [9].
According to the results of the audit assessment, one of the conclusions can be made:

1) organization's development strategy has been formed and implemented to fully meet the requirements of the external environment;

2) organization development strategy has been formed and implemented that does not meet the requirements of the external environment or does not fully comply (the extent and causes of non-compliance are identified; it is possible to develop measures aimed at eliminating the causes of non-compliance);

3) management decisions of the management to implement an organization's development strategy do not correspond to the strategy itself [3].

The study of the influence of changes in the external environment on the content of an organization's development strategy should be carried out in the following areas:

- economic factors;

- political factors;

- decision regulators;

- industry trends;

- technological factors;

- substitutes for products and services;

- new players in the market;

- other factors.

As a rule, the analysis of the factors mentioned above occurs within the framework of the PEST analysis, which can be considered an integral part of the strategic audit methodology.

PEST analysis is designed to identify political, economic, social and technological aspects of the external environment that affect the success of infrastructure projects and programs.

The political factors studied during the audit include: changes in legislation affecting the industry of a project or program, tax policy, relations with national and regional authorities, business regulation policies, the level of political stability in a country (region), approximation of state and local authorities etc. For example, at the present time, the most relevant is the study of the compliance of a company's activities with a state-run import substitution policy (the possibility of obtaining additional subsidies, market expansion due to changes in the competitive environment, etc.).

The main reason for studying economics is an assessment of the quality of resource allocation at the state level, which is the most important condition for an enterprise [9, 10]. As a rule, such economic factors are distinguished: general description of the situation in the economy of the country (industry), ruble rate, inflation, state of the banking system, change in the main external costs in the industry (gas, water, electricity), unemployment rate.

Using the social component of the PEST analysis, consumer preferences are determined. The social factors include: demographic changes, changes in the level and lifestyle, changes in tastes and preferences of consumers, changes in the level of education of the population, changes in income structure.

The aim of research of the technological component is identification of the trends in technological development, which are often the causes of changes and market losses, as well as the emergence of new products. These factors include: new inventions and the possibility of their application, the rate of change and the adaptation of new technologies in the industry, changes in communication 
technologies, the emergence of new materials, the trend of new products and services in the field [11].

A strategic audit takes into account the results of the analysis, which are drawn up in the form of a matrix, the components of which are the factors of the macroenvironment and the strength of their impact, estimated in points, ranks and other units of measurement. The results of the PEST analysis make it possible to assess the external economic situation that is developing in the sphere of production and commercial activity.

Let's consider applying a competence approach to organizing and conducting a strategic audit of an infrastructure project or program.

IPMA OCB [6] describes five groups of elements of an organization's competence in project management:

- management of projects, programs and portfolios is the component of corporate governance that is associated with projects, programs and portfolios. usually implemented by senior management, which is part of the management committees. they develop strategic visions, policies, recommendations, make decisions, monitor and monitor performance, and provide guidance on the sustainable development of competence in project, program, and portfolio management; - management of projects, programs and portfolios is the component of the organization's management system that is associated with projects, programs and portfolios. Usually implemented by managers of various levels of permanent and temporary units of the organization. They provide projects, programs and portfolios with people, develop methods, tools, recommendations, make decisions, monitor and control, and also provide guidance on the sustainable development of all elements of competence; - coordination of projects, programs and portfolios is aimed at ensuring the achievement of goals and expectations set by top management for the implementation of projects, programs and portfolios. Implemented by project managers, programs and portfolios with the support of functional managers.

The processes, structures and culture of projects, programs and portfolios should be consistent with the relevant processes, structures and culture of internal divisions and external organizations. They define:

- resource support projects, programs and portfolios aimed at ensuring the achievement of goals and expectations set by senior management, on the availability and use of resources. It is carried out by project managers, programs and portfolios with the support of functional units, such as finance, legal, procurement and technological support units. This element provides the definition of resource requirements, develops recommendations for the acquisition of resources and their sustainable development;

- competence of employees of projects, programs and portfolios is an element associated with the development of competence, increasing productivity and encouraging employees working in projects, programs, portfolios. It is carried out by project managers, programs and portfolios with the support of the HR department and other functional managers. This element provides the definition of staff competency requirements, an assessment of the current state of competence and the implementation of sustainable competence development in the field of project, program and portfolio management.
The mission defines the fundamental goal of the organization - why it was created and what it does. The vision clarifies what the organization wants to achieve in the future. These may be medium-term or long-term (for five years or more) goals. The wording of the vision must be positive, attract and inspire people.

The strategy shows how visions should be realized. It shows where to go and what to look for, to interested parties inside and outside the organization (for example, shareholders, customers and partners).

Developing an organization's mission, vision and strategy is an intensive process. Top management should involve leading experts and stakeholders in this process. The process usually begins with a strategic analysis, assessment of the current situation, past and future changes in the organization, modeling scenarios, or using other methods. It then analyzes and compares the position of the organization and the position of its main competitors, examines the existing strengths and weaknesses, as well as future opportunities and threats in comparison with competitors.

Strategy development can be carried out in different ways - «from top to bottom» and/or «from bottom to top» or it can be «Creative or spontaneous strategy development». At the conclusion of this process, it should become clear to all interested parties how the organization intends to realize the vision.

Strategies determine the requirements for the implementation of the current activities of the organization on the path to a long-term vision.

\section{Research results}

Organizational and managerial diagnostics of the organization's management system strategy is the first stage of work. The goal of organizational diagnostics of a strategy is identification of the main problems, their interconnection, and also suggestion of appropriate methods for developing the necessary solutions.

Within this stage, work is simultaneously being carried out in two directions: a study of the existing management system of the organization, an analysis of the problems of organizational development and a study of the existing technology of strategic project management. During diagnostics, teams of key employees are formed, self-assessments and interviews are conducted. As a result of the analysis of the obtained information, the range of major problems that impede the functioning and development of the organizational and management structure is determined, and ways to solve the identified problems are developed.

For diagnostics, the following methods are used:

- analysis of the life cycles of products, production technologies, processes of management of operating activities, development and implementation of business;

- analysis of managerial errors;

- work with organizational pathologies;

- developing diagnostic interviews;

- problem grouping;

- construction of graphs of problems, challenges and solutions.

Let's consider the use of these diagnostic methods, including self-diagnostics, in the development of a strategic management system using the example of a group of companies for the construction of the Confinement facility of the Chernobyl nuclear power plant. 
The diagnostics is carried out according to the method of analysis of product life cycles, development strategies, production technologies, and operational management processes.

6.1. Organizational and managerial diagnostics of the infrastructure project or program strategy. Competitive organizations have always aroused great interest among leading investment banks and burning envy among competitors. What determines their success? And how should managers act so that their organizations can follow the example of the «stars»?

Development at every step is formed on the basis of the philosophy of business life cycles, management systems, production technologies and products, innovative product platforms, integrated information systems and enterprise personnel. Intangible assets in the form of innovative platforms are actively used in development processes, while one of the criteria for the program's effectiveness is the level of capitalization of intangible assets when they are transformed into tangible ones.

This stage of diagnosis in the process of strategic audit determines the quantitative growth (products, personnel, customers, space, equipment, performance). In the «star» or- ganizations, success leads to some exaggerations of their capabilities and the emergence of errors that are easily forgiven.

Problems of strategic management of organizations by the IPMA Delta model [11-13] identified during diagnostic interviews (Table 1, Fig. 1, Table 2):

1. The project strategy is focused on financial indicators ensuring the quality of the product. There are no qualitative and measurable characteristics (KPI of performance indicators) of the results of development projects that are to be obtained.

2. Fuzzy wording allows to interpret the strategy in different ways.

3. Notification of failures, problems and strategy changes occur late, when it becomes impossible to hide this information.

4. Management is carried out on reactive principles The reaction is usually late. Strategic management should be proactive.

5. Problem analysis is not carried out regularly, but at the request of the management of the infrastructure program.

6. There are no formalized procedures and prescribed instructions that require paying more attention to the achievement of strategic goals.

Parameters for evaluating the strategy of projects and programs during the audit

\begin{tabular}{|c|c|c|}
\hline A2c & & Development and implementation of the project strategy \\
\hline \multirow{2}{*}{1} & \multirow[t]{2}{*}{ Questions } & Is the project strategy being developed and implemented? \\
\hline & & $\begin{array}{l}\text { In practice, in the best projects: } \\
\text { - take into account a number of external and internal factors when developing a project strategy; } \\
\text { - determine the key values of the project and ensure the compliance of the project strategy with it; } \\
\text { - decide on the most appropriate overall project management strategy and business model of the project based on a conscious assessment; } \\
\text { - make sure that the project's own strategy is consistent with the strategy and business model of the permanent organization; } \\
\text { - make sure that the project strategy is aimed at meeting the needs, expectations and requirements of the project stakeholders; } \\
\text { - ensure the compliance of the project strategy with the organizational, social, political, legal and technical complexity of the project } \\
\text { and its environment; } \\
\text { - innovations, training opportunities and project adaptation in accordance with the strategy are actively sought and evaluated; } \\
\text { - make sure that the project strategy includes a project management approach; } \\
\text { - development of a business continuity strategy throughout the project life cycle; } \\
\text { - make sure that the project strategy ensures that the results of the project are communicated to relevant stakeholders so that they } \\
\text { maintain sustainability; } \\
\text { - are aware of the core competencies, personal abilities and capabilities of their organization in order to develop partnership strategies } \\
\text { that enhance the value of the project; } \\
\text { - agree on the project strategy with the strategies of potential partners to create win-win situations and maximize the obligations of } \\
\text { their potential partners; } \\
\text { - ensure the participation of the project team in the development of the project strategy and get their commitment to it; } \\
\text { - systematically monitor and analyze project performance indicators to adapt the project strategy }\end{array}$ \\
\hline
\end{tabular}

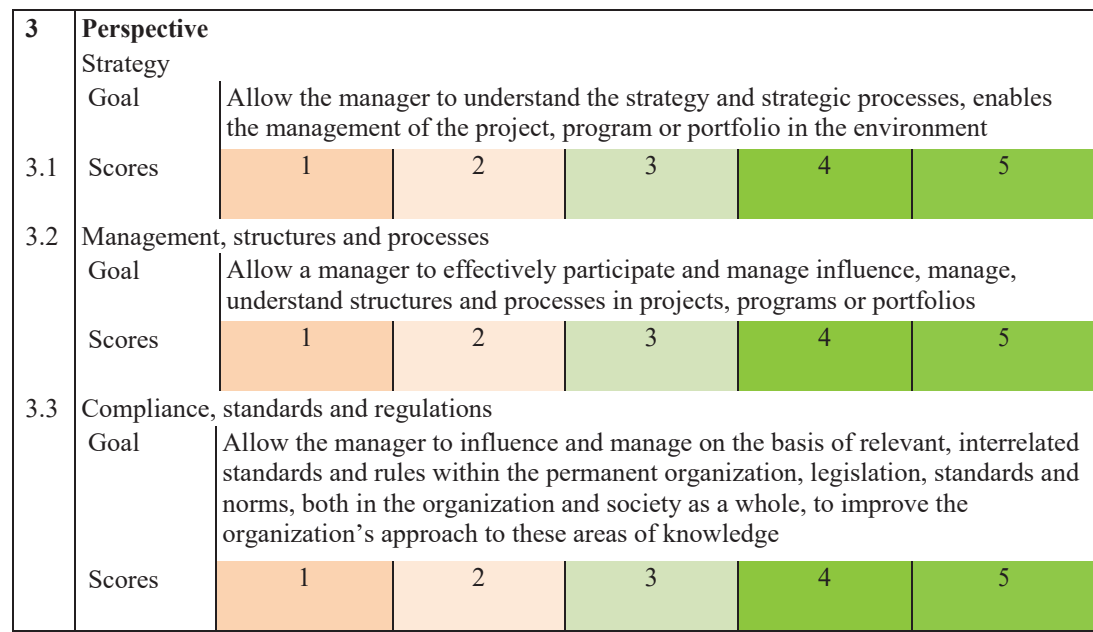

Fig. 1. Fragment of the self-assessment table of the competence of project and program managers in the strategic audit process 
Fragment of the audit list on the organization's audit by the IPMA Delta model

\begin{tabular}{|c|c|c|c|c|}
\hline \multirow{6}{*}{$\begin{array}{l}\text { 1. Manage- } \\
\text { ment }\end{array}$} & \multirow{6}{*}{$\begin{array}{l}\text { Mission, } \\
\text { vision } \\
\text { and } \\
\text { strategy }\end{array}$} & 5 & $\begin{array}{l}\text { Does the organization have a mission, vision and strategy for } \\
\text { managing projects, programs and project portfolios? }\end{array}$ & $\begin{array}{l}\text { Check brochures, mission description, project management } \\
\text { guide }\end{array}$ \\
\hline & & $\mathrm{T}$ & $\begin{array}{l}\text { Does the organization have processes for transforming strategies } \\
\text { for managing projects, programs and project portfolios? }\end{array}$ & $\begin{array}{l}\text { Assess the strategy, processes, project initiation, project } \\
\text { charter }\end{array}$ \\
\hline & & 5 & $\begin{array}{l}\text { How does the organization see the processes of using the pro- } \\
\text { cesses of leadership, management and implementation of projects, } \\
\text { programs and project portfolios? }\end{array}$ & Check accepted project management guidelines \\
\hline & & $\mathrm{T}$ & $\begin{array}{l}\text { How does the organization provide management resources to } \\
\text { achieve goals defined in projects, programs, and project portfolios? }\end{array}$ & $\begin{array}{l}\text { Check agreements between management and project, pro- } \\
\text { gram and portfolio managers for compliance with priorities }\end{array}$ \\
\hline & & $\mathrm{T}$ & $\begin{array}{l}\text { Are there standards and guidelines for managing risks and op- } \\
\text { portunities in projects, programs, and project portfolios, and are } \\
\text { there proper coordination with the organization's overall standards } \\
\text { for risks and opportunities? }\end{array}$ & Check internal standards, guidelines and regulations \\
\hline & & $\mathrm{T}$ & $\begin{array}{l}\text { Is there a process to select and involve external stakeholders in } \\
\text { the management of projects, programs and project porffolios? }\end{array}$ & Check selected, contracts and evaluate partners \\
\hline
\end{tabular}

6.2. Results of a strategic audit of an infrastructure project or program. The basis of ensuring the manageability of the company is the construction of an organizational management system.

Its main components are a structured system of basic definitions for successful management:

- vision of the company in perspective. What we want

to see the company in 3-5 years;

- company goals. Or they are SMART. Where to go

and where we would like to see the organization when realizing the goals;

- strategy for achieving goals. How to solve problems and respond to challenges;

- effective organizational structure of the organization;

- business processes and management procedures;

- organizational culture supports and motivates stakeholders for appropriate behavior.

Diagnostics of well-known companies that were certified according to the IPMA Delta model showed that their development projects are characterized by the absence of the above components of the management system. Among the goals of management and the majority of employees, the current activities (achievement of the required level of profitability) prevailed; the long-term and strategic orientation of the organization was extremely weak.

Manageability begins with the definition of goals around which the project must be integrated. First of all, it refers to the highest goals of the organization (mission, development philosophy, strategy).

Proper definition of the functions of departments and employees is very important for the accurate transfer of the objectives of the Project to their level. The more qualitatively the functions are formulated, the higher the consistency of the actions of the divisions and employees with both the general goals of the company and among themselves.

The proposed approach to the definition of role functions is based on the product method, when the function of the employee, department is determined through the necessary result of activity. In other words, they should be focused on a specific contribution to the solution of the tasks of the project as a whole.

The main thing that gives such a method of determining role-playing functions is a sequence in the formulation and transfer of common organizational goals to all levels of the organizational hierarchy, as well as horizontally between interrelated divisions and employees. At the same time, the maximum convergence, alignment of the goals of employees and departments with the goals of the project and managers is achieved. In addition, such functions become controlled, their execution is checked.

6.3. An example of an audit of the project implementation strategy for the Confinement Chornobyl NPP (Ukraine). In the 1980s, ChNPP (Chornobyl Nuclear Power Plant) was one of the most powerful nuclear power plants in the USSR. According to the strategic development plans of power industry of the Soviet Union, the ChNPP had to become the largest nuclear power plant in the world, consisting of six power units with an electric power of $1000 \mathrm{MWt}$ each (corresponding to $3200 \mathrm{MWt}$ of thermal power each respectively).

However, the devastating explosion of the fourth power unit of ChNPP on 26 April 1986 changed everything. The accident caused an emission of a huge amount of radioactive materials into the environment. About 600,000 people participated in elimination of consequences of the largest accident in the history of nuclear power, 200,000 people were evacuated and moved out of the area, and the health of 1.7 million people was undermined. The death-toll related to the Chernobyl accident, including those died from cancer years later, according to official data sources was estimated at 125,000 people.

In 1986 in just six months, in difficult radio-active conditions, scientists and experts of the former Soviet Union designed and constructed a protective cover for the damaged reactor, which was named the «Shelter», and was later renamed to «Sarcophagus». Implementation of design decisions during construction of «Shelter» object in a difficult radiation situation demanded implementation of a range of organizational and technical actions to ensure radiation protection of the personnel. Practical implementation of the fundamental principles of radiation safety while carrying out dangerous works was reliably supported by the strictest discipline and quickly developed and put into practice instructions and regulations of performance of all radiation-hazardous works.

In 1994 political leaders of the world, represented by the G7 (Group of Seven) and the European Union requested that the Ukraine stops operations of the remaining nuclear power stations of ChNPP. In 1995, the Ukraine signed 
a Memorandum of Understanding to stop power units of the ChNPP which eventually happened in 2000. A year later, the State Specialized Enterprise Chernobyl NPP (SSE ChNPP) was formed by the Ukrainian Government to decommission the existing power units and to transform the «Sarcophagus» into an ecologically safe system.

A complex three-stage program was started. In Stage 1 the objective was to stabilize the existing «Shelter» by increasing reliability and durability of the old structures and systems. Stage 2 was aimed at creating additional protective barriers, firstly through creating a new safe confinement providing necessary conditions (e. g. to ensure safety of the personnel, the local population and environment), preparatory technical work and the infrastructure for Stage 3. This included erection of the «New Safety Confinement» (NSC), which was an arched construction with a width of 257.4 meters, a height of 108.4 metres and the length of 150 metres. The NSC was designed for 100 years of operation to give the chance to carry out extraction of fuel-bearing materials and their conditioning for the subsequent safe storage (Fig. 2).

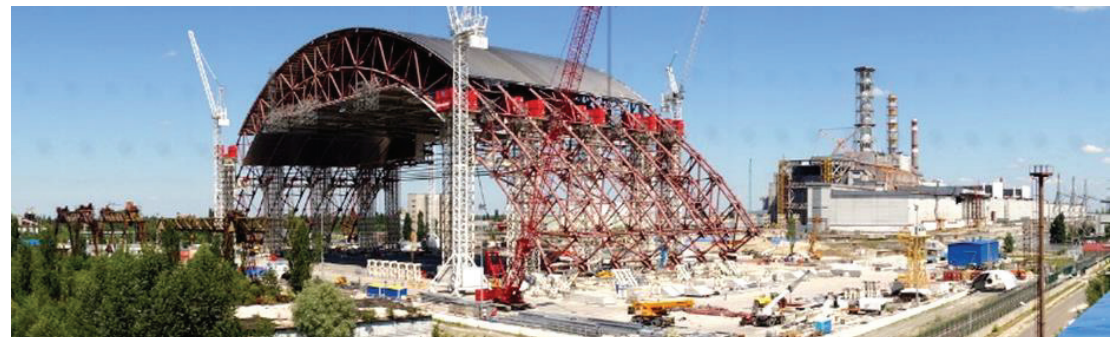

Fig. 2. «New Safety Confinement» after second lift of eastern section in 2013

After the erection of the NSC in 2015, Stage 3 would start and is planned to be carried out by 2023. It is aimed at the extraction of fuel-bearing materials and long existing radioactive waste, their conditioning and burial in radioactive waste storages in accordance with existing standards, removal from operation of the «Shelter» and dismantling of unstable structures of the «Sarcophagus».

Financing of works on the international project (the plan of implementation of measures on «Shelter» object) is carried out at the expense of the donor countries of the international Chernobyl Fund «Shelter» (ChFS). The European Bank of Reconstruction and Development (ERDB) provided the help to the government of Ukraine in organising of the international conference on fund-raising to cover the missing financing of the program. As a whole, the construction of the NSC arch is expected to cost in excess of 1 billion EUR.

One of the challenges for the ChNPP was the lack of personnel with sufficient experience in implementing such a complex program and with coordination of all related projects. A Project Management Unit (PMU) was formed to establish standards for project and program management in accordance with the internationally acknowledged standards [11]. The PMU of ChNPP worked closely together with Ukrainian Project Management Association (UPMA) and Kyiv National University of Construction and Architecture to develop the standards and the competence of personnel involved in the program and projects with application of IPMA OCB model (IPMA OCB, 2013).

\section{SWOT analysis of research results}

Strengths. The strength of the strategic audit is assessment of the strategy based on the model of project and program management recognized by international practice $[11,12]$. The model allows to assess the level of uncertainty of the goals and results of infrastructure projects.

Weaknesses. Weaknesses are determined by the limitations of the model to track the dynamics of achieving strategic goals based on the development of the competence of the management team. Such tracking requires a repeat strategic audit.

Opportunities. Opportunities in the application of strategic audit associated with the assessment, which may lead to clarification or changes in the system of goals and directions of movement of infrastructure projects.

Threats. Threats are associated with the initial uncertainty of infrastructure projects, which significantly complicates the formation of goals and strategies to achieve them.

\section{Conclusions}

1. The interrelation of «organization development strategy» and «strategic audit of infrastructure projects and programs» concepts is defined. The results of the organization's self-assessment according to the IPMA Delta organizational competence model on the life-cycle diagram made by the team and the leader indicated two stages following one after the other - «forward and more» and «youth».

This approach suggests that the values of the leader and team members are the same, which is a factor supporting development. In this case, the implementation of these goals falls on the head, as evidenced by the lack of understanding of the direction of movement.

The readiness of project staff for development, both company and professional and personal development, is indicated by the presence of problems «There is a lack of managerial competencies in the team» and «unprocessed personnel training program does not allow developing the skills necessary for the project». Development is a systematic process and should be regular, which is impossible without system planning and monitoring. In addition, an important structural component of the organizational order is a motivating environment.

2. The approaches to the audit assessment of the ability of the response of the infrastructure project management system to uncertainty factors, changes in the external environment and the degree of adequacy of the organizational and economic elements of the management system that ensure the achievement of strategic goals are substantiated. An algorithm for conducting a strategic audit on the organization's technological maturity model (IPMA OCB) is presented.

In the model used, five groups of elements of the organization's competence in the field of project management are evaluated:

1) management of projects, programs and portfolios as an element of corporate governance, which is associated with projects, programs and portfolios; 
2) project management, programs and portfolios as part of the organization's management system and is implemented by managers at various levels of the permanent and temporary units of the organization;

3) coordination of projects, programs and portfolios, ensuring the achievement of goals and expectations set by top management;

4) resource support of projects, programs and portfolios, which is aimed at achieving the goals and expectations set by top management;

5) competence of the staff of projects, programs and portfolios, which is associated with the development of competence, increasing productivity and encouraging employees working in projects, programs, portfolios.

\section{Література}

1. Donaldson G. A new tool for boards: the strategic audit // Harvard business review. 1995. Vol. 99.

2. Wheelen T. L., Hunger J. D. Concepts in Strategic Management and Business Policy: Achieving Sustainability. PrenticeHall, 2009. 456 p.

3. Kerzner H. Strategic Planning for Project Management Using a Project Management Maturity Model. John Wiley \& Sons Inc, 2001. $272 \mathrm{p}$.

4. Kerzner H. In search of excellence in Project Management. Wiley, 1998. 288 p.

5. Guariano N., Giaretta P. Ontologies and Knowledge Bases. Towards a Terminological Clarification // Towards Very Large Knowledge Bases: Knowledge Building and Knowledge Sharing. Amsterdam: IOS Press, 1995. P. 25-32.
6. IPMA Organisational Competence Baseline (IPMA OCB). IPMA, 2013. $137 \mathrm{p}$

7. Dzhenser P., Hassi D. Analiz sil'nyh i slabyh storon kompanii opredelenie strategicheskih vozmozhnostei. Moscow: Vil'iams, 2003. 368 p.

8. Forsberg K., Mooz H., Cotterman H. Visualizing Project Management. New York: John Wiley and Sons, 2005. 480 p.

9. Gudenitsa O., Shishov L. Strategicheskii audit v kommercheskih organizatsiiah. Rostov on Don: BUPK, 2008. 148 p.

10. Strategicheskii razryv: Tekhnologii voploscheniia korporativnoi strategii v zhizn' / Koveni M., Genster D., Hartlen B., King D. Moscow: Al'pina Biznes Buks, 2004. 232 p.

11. D. Bushuyev S., Friedrich Wagner R. IPMA Delta and IPMA Organisational Competence Baseline (OCB): New approaches in the field of project management maturity // International Journal of Managing Projects in Business. 2014. Vol. 7, Issue 2. P. 302-310. doi: http://doi.org/10.1108/ijmpb-10-2013-0049

12. Bushuyev S., Kharitonov D., Rogozina V. Organizational Project Management pathology // Management of development complex system. 2012. Issue 10. P. 5-8.

Bushuyev Sergey, Doctor of Technical Sciences, Professor, Head of Department of Project Management, Kyiv National University of Construction and Architecture,Ukraine, e-mail: SBushuyev@ukr.net, ORCID: http://orcid.org/0000-0002-7815-8129

Kozyr Boris, PhD, Associate Professor, Department of Project Management, Kyiv National University of Construction and Architecture, Ukraine, ORCID: http://orcid.org/0000-0003-3400-4571

Zaprivoda Alina, Postgraduate Student, Department of Project Management, Kyiv National University of Construction and Architecture, Ukraine, ORCID: http://orcid.org/0000-0003-4434-326X 